\title{
A Study on Biochemical Parametrs in Patients with Rickettsial Infection
}

\author{
Krishna Kumar Naik' ${ }^{1}$, Shivaprasad ${ }^{2}$ \\ ${ }^{1}$ Assistant Professor, Department of General Medicine, KIMS, Koppal, Karnataka, ${ }^{2}$ Senior Resident, Department of General Medicine, KIMS, Koppal, \\ Karnataka.
}

\section{Abstract}

Background: The traditional views of tick-borne rickettsioses as endemic diseases with largely focal distributions and limited host and geographic ranges, predetermined seasonality and defined tick associations became obsolete or at least very incomplete. This expansion of awareness about the existence of other rickettsial agents with varied clinical and epidemiological attributes has been thoroughly reviewed but it has presented new challenges to the medical and public health communities. Subjects and Methods: The clinical presentation and multiple organ dysfunctions in these patients were evaluated with a special focus on the renal manifestation and hepatic manifestations. The study population included all the patients presenting fever, rash and were diagnosed with rickettsial disease by clinical examination. A total of 60 subjects, satisfying the inclusion and exclusion criteria were included in the final analysis. The sample size was calculated assuming the expected proportion of rickettsial infection as $11 \%$ among fever cases as per previously published studies, with a precision of $8 \%$ and $95 \%$ confidence level. Results: The mean AST in the 80 titre was $140.43 \pm 79.92$, it was $285.89 \pm 184.95$ in 160 titre, $364.92 \pm 89.69$ in 320 titre group and $579.29 \pm 106.26$ in 640 titre group. The mean difference of AST 145.47 in 160 titre group was statistically significant (p value $<0.001$ ), 224.50 in 320 titre group was statistically significant (p value<0.001), and in 640 titre group 438.86 was statistically significant. (P- Value <0.001). Conclusion: The study has highlighted the need to have a high index of suspicion to enhance the diagnosis of ricketsial diseases and also the strong association between weilfelixtitre and liver and renal dysfunction.

Keywords: Rickettsioses, Weil Felix Titre, Biochemical Parameters.

Corresponding Author: Dr. Shivaprasad, Senior Resident, Department of General Medicine, KIMS, Koppal, Karnataka.

Received: July 2019

Accepted: July 2019

\section{Introduction}

Right from the very early time in the history, there were many insults caused by the Rickettsial infections. The most evident was that of the epidemic typhus upshot in Russia during the late 1910s and early 1920 s where in about three million lives were spared. There is convincing evidence of this disease to be considered a public health threat with its emergence characteristics on at-risk population. In the1940s the United States (US) reported an alarming rise of murine typhus cases, which was then followed by RMSF surge in 1970s and by the ehrlichioses (human) ascent later in the 1990s. ${ }^{[1]}$ The increased burden of the disease in a specific geographical region has added insight into the transmission cycle happening in vectors, that envisages trans-ovarian and trans-stadial route of transmission of Rickettsial pathogens occurring in vectors. ${ }^{[2]}$ This further added the epidemiological values to this disease.

The incidence of tick-borne rickettsial diseases is peaking. It is currently going through its second pronounced increase in the last 40 years. Since the 1970s, four endemic rickettsioses Rocky Mountain Spotted fever (RMSF), Mediterranean spotted fever (MSF), North Asian tick typhus (NATT) and
Queensland tick typhus (QTT), have been on a continuous increase. The incidence of Japanese spotted fever has alsoincreased steadily since its discovery in the mid-1980s. It is possible that other tick-borne rickettsial infections have shown similar increases but only these more common and severe diseases have much useful, albeit based on the limits imposed by contemporary views, disease surveillance information. The incidence of RMSF has raised its toll to the maximum US during 2004. The ticks (Rhipicephalussanguineus) were noted in the brown dogs of the residents which showed positivity of $R$. rickettsii organisms in it. ${ }^{[3]}$

Blanton L. S. et. Al. ${ }^{[4]}$ have reviewed the understanding of this disease by the countries and the precautions taken by the travelers to prevent this from occurring. The reports were daunting as the study found increasing prevalence of disease in tropics (travelers most preferred location) in addition to its re-emergence in Bulgaria following poor vector control measures. Furthermore, the sequel of the disease (Rickettsia rickettsii) sustains the same level in Central and South America. There was also evidence suggesting the declining efficacy of fluoroquinolones that were used for the treatment of milder conditions. This exposes the weakened preparation of the countries to control this disease. 
Sagin D. D. et. Al. ${ }^{[5]}$ have identified and described the Rickettsial infection in remote Orang Ulu villages in upper Rejang River, Sarawak, Malaysia. People in 5 Orang Ulu villages in Sarawak, Malaysia, there were $9.6 \%$ who were positive for typhus out of which, $3.8 \%$ were positive for tick typhus (7/11), while scrub typhus was positive in (4/11) or endemic typhus positivity was found in (1/11). The incidence of typhus was found to be higher among semi-nomadic Penans than that of the settled Kayans.

Mittal V. et. Al., ${ }^{[6]}$ in their quest to find the profile of Rickettsial infections in Delhi have detected scrub typhus (48.2\%) as the commonest Rickettsial infections followed by spotted fever group (27.5\%) and typhus group (6.8\%) between 2005 and 2009. They have also found Leptotombidiumdeliense mite on the rodents during the entomological survey.

Rahi M. et. Al. ${ }^{[7]}$ have postulated that the scrub typhus, murine flea-borne typhus, Indian tick typhus and Q fever are the major groups of rickettsioses, commonly reported diseases in India. Rickettsial infections are generally incapacitating and difficult to diagnose; untreated cases have case fatality rates as high as 30-45 percent with multiple organ dysfunctions, when not diagnosed promptly and appropriately treated.

Ahmad S. et. Al. ${ }^{[8]}$ have reported nine cases of scrub typhus from the Garhwal region of the newly created north Indian state of Uttarakhand, a region not previously known to harbor the vector. It stressed the significance of entomological studies that are needed to find the density of the vector and for institution of vector control measures in order to prevent this relatively benign, yet potentially fatal, clinical entity from spiraling into a major public health issue. Being an emerging and re-emerging disease this attribute is critical for a disease of public health importance. "The traditional views of tick-borne rickettsioses as endemic diseases with largely focal distributions and limited host and geographic ranges, predetermined seasonality and defined tick associations became obsolete or at least very incomplete. This expansion of awareness about the existence of other rickettsial agents with varied clinical and epidemiological attributes has been thoroughly reviewed but it has presented new challenges to the medical and public health communities. The paradigm shift is due to the fact that numerous rickettsiae of unknown to variable degrees of pathogenicity for humans co-circulate in overlapping geographic regions and may even be found in the same tick species."

\section{Subjects and Methods}

The study was a prospective observational study. Cases of fever admitted in the study period in our hospital were followed up on the basis of weilfelix positivity. The clinical presentation and multiple organ dysfunctions in these patients were evaluated with a special focus on the renal manifestation and hepatic manifestations. The study population included all the patients presenting fever, rash and were diagnosed with rickettsial disease by clinical examination

A total of 60 subjects, satisfying the inclusion and exclusion criteria were included in the final analysis. The sample size was calculated assuming the expected proportion of rickettsial infection as $11 \%$ among fever cases as per previously published studies, with a precision of $8 \%$ and 95\% confidence level.

The required sample size, as per the above calculation was 59. To account for a 5\% nonparticipation rate it was decided to sample 63 subjects, so that final analysis can include not less than 59 subjects. The final analysis has included 60 subjects at the end of data collection period.

All the eligible study subjects, satisfying inclusion and exclusion criteria were recruited into the study by convenient sampling.

The association between quantitative blood pressure variables and any positive weilfelix was assessed by comparing the mean values. The mean differences along with their $95 \%$ CI were presented. ANOVA was used to assess statistical significance. The association between all symptoms of the disease and weilfelixtitre was assessed by cross tabulation and comparison of percentages. Chi square test was used to test statistical significance.

\section{Results}

Table 1: Comparison of mean hemoglobin across study groups (N=60)

\begin{tabular}{|c|c|c|c|c|c|}
\hline \multirow[t]{2}{*}{$\begin{array}{c}\text { Overall } \\
\text { Weil- } \\
\text { Felix } \\
\text { titre }\end{array}$} & \multirow[t]{2}{*}{$\begin{array}{c}\text { Haemoglobin } \\
\text { Mean } \pm \text { SD }\end{array}$} & \multirow[t]{2}{*}{$\begin{array}{c}\text { Mean } \\
\text { Difference }\end{array}$} & \multicolumn{2}{|c|}{$\begin{array}{c}95 \% \\
\text { Confidence } \\
\text { Interval for } \\
\text { Mean } \\
\end{array}$} & \multirow[t]{2}{*}{$\begin{array}{c}\mathbf{P} \\
\text { Value }\end{array}$} \\
\hline & & & $\begin{array}{l}\text { Lower } \\
\text { Bond }\end{array}$ & $\begin{array}{l}\text { Upper } \\
\text { Bond }\end{array}$ & \\
\hline 80 & $11.88 \pm 0.67$ & & & & \\
\hline 160 & $10.17 \pm 1.77$ & 1.71 & 0.58 & 2.83 & 0.004 \\
\hline 320 & $9.78 \pm 2.59$ & 2.10 & 0.84 & 3.35 & $<0.001$ \\
\hline 640 & $8.66 \pm 2.25$ & 3.22 & 1.67 & 4.78 & $<0.001$ \\
\hline
\end{tabular}

The mean hemoglobin in the 80 titre was $11.88 \pm 0.67$, it was $10.17 \pm 1.77$ in 160 titre, $9.78 \pm 2.59$ in 320 titre group and $8.66 \pm 2.25$ in 640 titre group. The mean difference of hemoglobin 1.71 in 160 titre group was statistically significant ( $\mathrm{p}$ value0.004), 2.10 in 320 titre group was statistically significant ( $\mathrm{p}$ value $<0.001$ ), and in 640 titre group 3.22 was statically significant. (P-Value $<0.001)$.

Table 2: Comparison of mean total count across study groups (N=60)

\begin{tabular}{|c|c|c|c|c|c|}
\hline \multirow{2}{*}{$\begin{array}{l}\text { Overall } \\
\text { Weil- } \\
\text { Felix } \\
\text { titre }\end{array}$} & \multirow[t]{2}{*}{$\begin{array}{l}\text { Total Count } \\
\text { Mean } \pm \text { SD }\end{array}$} & \multirow[t]{2}{*}{$\begin{array}{l}\text { Mean } \\
\text { Difference }\end{array}$} & \multicolumn{2}{|c|}{$\begin{array}{l}\text { 95\% Confidence } \\
\text { Interval for Mean }\end{array}$} & \multirow[t]{2}{*}{$\begin{array}{l}\mathbf{P} \\
\text { Value }\end{array}$} \\
\hline & & & $\begin{array}{l}\text { Lower } \\
\text { Bond }\end{array}$ & $\begin{array}{l}\text { Upper } \\
\text { Bond }\end{array}$ & \\
\hline 80 & $7978.57 \pm 2895.8$ & & & & \\
\hline 160 & $7094.74 \pm 2285.33$ & 883.83 & -759.06 & 2526.73 & 0.286 \\
\hline 320 & $7465.38 \pm 2693.46$ & 513.19 & $\begin{array}{l}- \\
1317.97\end{array}$ & 2344.34 & 0.577 \\
\hline 640 & $5864.29 \pm 2118.71$ & 2114.29 & -150.29 & 4378.86 & 0.067 \\
\hline
\end{tabular}

The mean total count in the 80 titre was $7978.57 \pm 2895.8$, it was $7094.74 \pm 2285.33$ in 160 titre, $7465.38 \pm 2693.46$ in 320 titre group and $5864.29 \pm 2118.71$ in 640 titre group. The mean difference of total count 883.83 in 160 titre group was statistically not significant ( $\mathrm{p}$ value 0.286 ), 513.19 in 320 titre group was statistically not significant (p value 0.577 ), and in 640 titre group 2114.29 was statically not significant. (P- value0.067). 
Table 3: Comparison of mean platelet across study groups (N=60)

\begin{tabular}{|l|c|l|l|l|c|}
\hline $\begin{array}{c}\text { Overall } \\
\text { Weil- } \\
\begin{array}{c}\text { Felix } \\
\text { titre }\end{array}\end{array}$ & $\begin{array}{c}\text { Platelet Mean } \pm \\
\text { SD }\end{array}$ & $\begin{array}{c}\text { Mean } \\
\text { Difference }\end{array}$ & \multicolumn{2}{|c|}{$\begin{array}{c}\text { 95\% Confidence } \\
\text { Interval for Mean }\end{array}$} & $\begin{array}{c}\text { P } \\
\text { Value }\end{array}$ \\
\cline { 4 - 5 } & & & $\begin{array}{c}\text { Lower } \\
\text { Bond }\end{array}$ & $\begin{array}{c}\text { Upper } \\
\text { Bond }\end{array}$ & \\
\hline 80 & $52333.98 \pm 47613.68$ & & & & \\
\hline 160 & $60631.71 \pm 35052.44$ & 8297.74 & - & 31061.40 & 0.468 \\
\hline 320 & $58153.85 \pm 18365.94$ & 5819.87 & - & 31191.99 & 0.648 \\
\hline 640 & $21285.71 \pm 10209.71$ & 31048.26 & -329.28 & 62425.80 & 0.052 \\
\hline
\end{tabular}

The mean platelet in the 80 titre was $52333.98 \pm 47613.68$, it was $60631.71 \pm 35052.44$ in 160 titre, $58153.85 \pm 18365.94$ in 320 titre group and $21285.71 \pm 10209.71$ in 640 titre group. The mean difference of platelet 8297.74 in 160 titre group was statistically not significant (p value 0.468 ), 5819.87 in 320 titre group was statistically not significant $(\mathrm{p}$ value 0.648 ), and in 640 titre group 31048.26 was statically not significant. (P- value 0.052 ).

Table 4: Comparison of mean total bilirubin across study groups $(\mathbf{N}=\mathbf{6 0})$

\begin{tabular}{|l|l|l|l|l|l|}
\hline $\begin{array}{c}\text { Overall } \\
\text { Weil- } \\
\begin{array}{c}\text { Felix } \\
\text { titre }\end{array}\end{array}$ & $\begin{array}{c}\text { Total } \\
\text { Bilirubin } \\
\text { Mean } \pm \text { SD }\end{array}$ & $\begin{array}{c}\text { Mean } \\
\text { Difference }\end{array}$ & \multicolumn{2}{|c|}{$\begin{array}{c}\text { 95\% Confidence } \\
\text { Interval for Mean }\end{array}$} & $\begin{array}{c}\text { P } \\
\text { Value }\end{array}$ \\
\cline { 4 - 5 } & & $\begin{array}{c}\text { Lower } \\
\text { Bond }\end{array}$ & $\begin{array}{c}\text { Upper } \\
\text { Bond }\end{array}$ & \\
\hline 80 & $1.54 \pm 0.51$ & & & & \\
\hline 160 & $2 \pm 1.11$ & 0.46 & -0.17 & 1.09 & 0.146 \\
\hline 320 & $4.41 \pm 1.42$ & 2.87 & 2.17 & 3.57 & $<0.001$ \\
\hline 640 & $6.63 \pm 0.76$ & 5.09 & 4.23 & 5.96 & $<0.001$ \\
\hline
\end{tabular}

The mean total bilirubin in the 80 titre was $1.54 \pm 0.51$, it was $2 \pm 1.11$ in 160 titre, $4.41 \pm 1.42$ in 320 titre group and $6.63 \pm 0.76$ in 640 titre group. The mean difference of total bilirubin 0.46 in 160 titre group was statistically not significant ( $p$ value 0.146 ), 2.87 in 320 titre group was statistically significant ( $\mathrm{p}$ value $<0.001$ ) and in 640 titre group 5.09 was statistically significant. (P- Value $<0.001)$.

\begin{tabular}{|c|c|c|c|c|c|}
\hline Tabl & anari & $\operatorname{an~} \mathrm{A}$ & ogs & & $=60)$ \\
\hline $\begin{array}{c}\text { Overall } \\
\text { Weil- } \\
\text { Felix }\end{array}$ & $\begin{array}{c}\text { AST Mean } \pm \\
\text { SD }\end{array}$ & $\begin{array}{c}\text { Mean } \\
\text { Difference }\end{array}$ & $\begin{array}{r}95 \% \mathrm{C} \\
\text { InteI } \\
\mathrm{N}\end{array}$ & $\begin{array}{l}\text { fidence } \\
\text { al for } \\
\text { an }\end{array}$ & $\begin{array}{c}\mathbf{P} \\
\text { Value }\end{array}$ \\
\hline titre & & & $\begin{array}{c}\text { Lower } \\
\text { Bond }\end{array}$ & $\begin{array}{c}\text { Upper } \\
\text { Bond }\end{array}$ & \\
\hline 80 & $140.43 \pm 79.92$ & & & & \\
\hline 160 & $285.89 \pm 184.95$ & 145.47 & 64.71 & 226.22 & $<0.001$ \\
\hline 320 & $364.92 \pm 89.69$ & 224.50 & 134.49 & 314.50 & $<0.001$ \\
\hline 640 & $579.29 \pm 106.26$ & 438.86 & 327.55 & 550.17 & $<0.001$ \\
\hline
\end{tabular}

The mean AST in the 80 titre was $140.43 \pm 79.92$, it was $285.89 \pm 184.95$ in 160 titre, $364.92 \pm 89.69$ in 320 titre group and $579.29 \pm 106.26$ in 640 titre group. The mean difference of AST 145.47 in 160 titre group was statistically significant ( $\mathrm{p}$ value $<0.001$ ), 224.50 in 320 titre group was statistically significant ( $\mathrm{p}$ value $<0.001$ ), and in 640 titre group 438.86 was statistically significant. (P-Value <0.001).

\begin{tabular}{|c|c|c|c|c|c|}
\hline \multicolumn{6}{|c|}{ Table 6: Comparison of mean ALT across study groups $(\mathrm{N}=60)$} \\
\hline \multirow{2}{*}{$\begin{array}{c}\text { Overall } \\
\text { Weil- } \\
\text { Felix } \\
\text { titre }\end{array}$} & \multirow[t]{2}{*}{$\begin{array}{c}\text { AST Mean } \pm \\
\text { SD }\end{array}$} & \multirow[t]{2}{*}{$\begin{array}{c}\text { Mean } \\
\text { Difference }\end{array}$} & \multicolumn{2}{|c|}{$\begin{array}{c}\text { 95\% Confidence } \\
\text { Interval for } \\
\text { Mean }\end{array}$} & \multirow[t]{2}{*}{$\begin{array}{c}\mathbf{P} \\
\text { Value }\end{array}$} \\
\hline & & & $\begin{array}{l}\text { Lower } \\
\text { Bond }\end{array}$ & $\begin{array}{c}\text { Upper } \\
\text { Bond }\end{array}$ & \\
\hline 80 & $154.52 \pm 112.16$ & & & & \\
\hline 160 & $295.11 \pm 200.03$ & 140.58 & 49.50 & 231.66 & 0.003 \\
\hline 320 & $375.23 \pm 113.79$ & 220.71 & 119.19 & 322.23 & $<0.001$ \\
\hline 640 & $484.14 \pm 67.93$ & 329.62 & 204.07 & 455.17 & $<0.001$ \\
\hline
\end{tabular}

The mean ALT in the the 80 titre was $154.52 \pm 112.16$, it was $295.11 \pm 200.03$ in 160 titre, $375.23 \pm 113.79$ in 320 titre group and $484.14 \pm 67.93$ in 640 titre group. The mean difference of ALT 140.58 in 160 titre group was statistically significant ( $\mathrm{p}$ value 0.003 ), 220.71 in 320 titre group was statistically significant ( $\mathrm{p}$ value $<0.001$ ), and in640 titre group 329.62 was statistically significant. (P-Value $<0.001$ ).

Table 7: Comparison of mean ALP across study groups (N=60)
\begin{tabular}{|l|l|l|l|l|l|}
\hline $\begin{array}{l}\text { Overall } \\
\begin{array}{l}\text { Weil- } \\
\text { Felix } \\
\text { titre }\end{array}\end{array}$ & $\begin{array}{l}\text { ALP Mean } \\
\pm \text { SD }\end{array}$ & $\begin{array}{l}\text { Mean } \\
\text { Difference }\end{array}$ & $\begin{array}{l}\mathbf{9 5 \%} \text { Confidence } \\
\text { Interval for Mean }\end{array}$ & \multirow{2}{*}{ Value } \\
\cline { 4 - 6 } & & $\begin{array}{l}\text { Lower } \\
\text { Bond }\end{array}$ & $\begin{array}{l}\text { Upper } \\
\text { Bond }\end{array}$ & \\
\hline 80 & $149.76 \pm 64.42$ & & & & \\
\hline 160 & $209.74 \pm 85.09$ & 59.97 & 11.96 & 107.99 & 0.015 \\
\hline 320 & $254.54 \pm 67.09$ & 104 & 51.25 & 158.30 & $<0.001$ \\
\hline 640 & $356.43 \pm 94.55$ & 206.67 & 140.48 & 272.86 & $<0.001$ \\
\hline
\end{tabular}

The mean ALP in the 80 titre was $149.76 \pm 64.42$, it was $209.74 \pm 85.09$ in 160 titre, $254.54 \pm 67.09$ in 320 titre group and $356.43 \pm 94.55$ in 640 titre group. The mean difference of ALP 59.97 in 160 titre group was statistically significant (p value 0.015 ), 104.78 in 320 titre group was statistically significant ( $\mathrm{p}$ value $<0.001$ ), and in 640 titre group 206.67 was statistically significant.

Table 8: Comparison of mean urea across study groups $(\mathbf{N}=60)$
\begin{tabular}{|c|c|c|c|c|c|}
\hline $\begin{array}{c}\text { Overall } \\
\text { Weil- }\end{array}$ & $\begin{array}{c}\text { Urea Mean } \\
\pm \text { SD } \\
\begin{array}{c}\text { Felix } \\
\text { titre }\end{array}\end{array}$ & $\begin{array}{c}\text { Mean } \\
\text { Difference }\end{array}$ & $\begin{array}{c}\text { 95\% Confidence } \\
\text { Interval for Mean }\end{array}$ & $\begin{array}{c}\mathbf{P} \\
\text { Value }\end{array}$ \\
\cline { 4 - 6 } & & & $\begin{array}{c}\text { Lower } \\
\text { Bond }\end{array}$ & $\begin{array}{c}\text { Upper } \\
\text { Bond }\end{array}$ & \\
\hline 80 & $40.86 \pm 7.92$ & & & & \\
\hline 160 & $46.53 \pm 14.59$ & 5.67 & -2.53 & 13.87 & 0.172 \\
\hline 320 & $60.85 \pm 15.77$ & 19.99 & 10.85 & 29.13 & $<0.001$ \\
\hline 640 & $72.29 \pm 14.67$ & 31.43 & 20.13 & 42.73 & $<0.001$ \\
\hline
\end{tabular}

The mean urea in the 80 titre was $40.86 \pm 7.92$, it was 46.53 \pm 14.59 in 160 titre, $60.85 \pm 15.77$ in 320 titre group and $72.29 \pm 14.67$ in 640 titre group. The mean difference of urea 5.67 in 160 titre group was statistically not significant (p value0.172), 19.99 in 320 titre group was statistically significant ( $\mathrm{p}$ value $<0.001$ ) and in 640 titre group 31.43 was statistically significant (P-Value $<0.001)$.

Table 9: Comparison of mean serum sodium across study groups $(\mathbf{N}=60)$

\begin{tabular}{|c|c|c|c|c|c|}
\hline \multirow{2}{*}{$\begin{array}{c}\text { Overall } \\
\text { Weil- } \\
\text { Felix } \\
\text { titre }\end{array}$} & \multirow{2}{*}{$\begin{array}{c}\text { Serum } \\
\text { Sodium } \\
\text { Mean } \pm \text { SD }\end{array}$} & \multirow[t]{2}{*}{$\begin{array}{c}\text { Mean } \\
\text { Difference }\end{array}$} & \multicolumn{2}{|c|}{$\begin{array}{l}95 \% \text { Confidence } \\
\text { Interval for Mean }\end{array}$} & \multirow[t]{2}{*}{$\begin{array}{c}\mathbf{P} \\
\text { Value }\end{array}$} \\
\hline & & & $\begin{array}{l}\text { Lower } \\
\text { Bond }\end{array}$ & $\begin{array}{l}\text { Upper } \\
\text { Bond }\end{array}$ & \\
\hline 80 & $129.76 \pm 7.49$ & & & & \\
\hline 160 & $119.74 \pm 10.28$ & 10.03 & 4.63 & 15.42 & $<0.001$ \\
\hline 320 & $107.54 \pm 7.45$ & 22.22 & 16.22 & 28.23 & $<0.001$ \\
\hline 640 & $100.29 \pm 7.7$ & 29.48 & 22.05 & 36.91 & $<0.001$ \\
\hline
\end{tabular}

The mean sodium in the 80 titre was $129.76 \pm 7.49$, it was $119.74 \pm 10.28$ in 160 titre, $107.54 \pm 7.45$ in 320 titre group and $100.29 \pm 7.7$ in 640 titre group. The mean difference of serum sodium 10.03 in 160 titre group was statistically significant ( $\mathrm{p}$ value $<0.001$ ), 22.22 in 320 titre group was statistically significant ( $\mathrm{p}$ value $<0.001$ ) and in 640 titre group 29.48 was statically significant. (P-Value $<0.001)$. 
Table 10: Comparison of mean serum creatinine across study groups $(\mathbf{N}=60)$

\begin{tabular}{|c|c|c|c|c|c|}
\hline \multirow{2}{*}{$\begin{array}{c}\text { Overall } \\
\text { Weil- } \\
\text { Felix } \\
\text { titre }\end{array}$} & \multirow{2}{*}{$\begin{array}{c}\text { Serum } \\
\text { Creatinine } \\
\text { Mean } \pm \text { SD }\end{array}$} & \multirow[t]{2}{*}{$\begin{array}{c}\text { Mean } \\
\text { Difference }\end{array}$} & \multicolumn{2}{|c|}{$\begin{array}{l}\text { 95\% Confidence } \\
\text { Interval for Mean }\end{array}$} & \multirow[t]{2}{*}{$\begin{array}{c}\mathbf{P} \\
\text { Value }\end{array}$} \\
\hline & & & $\begin{array}{c}\text { Lower } \\
\text { Bond }\end{array}$ & $\begin{array}{l}\text { Upper } \\
\text { Bond }\end{array}$ & \\
\hline 80 & $1.32 \pm 0.38$ & & & & \\
\hline 160 & $1.67 \pm 0.69$ & 0.35 & -0.04 & 0.74 & $<0.077$ \\
\hline 320 & $2.43 \pm 0.64$ & 1.11 & 0.68 & 1.55 & $<0.001$ \\
\hline 640 & $3.33 \pm 0.87$ & 2.01 & 1.47 & 2.55 & $<0.001$ \\
\hline
\end{tabular}

The mean serum creatinine in the 80 titre was $1.32 \pm 0.38$, it was $1.67 \pm 0.69$ in 160 titre, $2.43 \pm 0.64$ in 320 titre group and $3.33 \pm 0.87$ in 640 titre group. The mean difference of serum creatinine 0.35 in 160 titre group was statistically not significant ( $\mathrm{p}$ value 0.077 ), 1.11 in 320 titre group was statistically significant ( $\mathrm{p}$ value $<0.001$ ) and in 640 titre group 2.01 was statically significant. (P-Value $<0.001)$.

\section{Discussion}

The mean hemoglobin in the 80 titre was $11.88 \pm 0.67$, it was $10.17 \pm 1.77$ in 160 titre, $9.78 \pm 2.59$ in 320 titre group and $8.66 \pm 2.25$ in 640 titre group. The mean difference of hemoglobin 1.71 in 160 titre group was statistically significant $(\mathrm{p}$ value $=0.004), 2.10$ in 320 titre group was statistically significant ( $\mathrm{p}$ value $<0.001$ ), and in 640titre group 3.22 was statically significant. (P-Value $<0.001$ ).

The mean total count in the 80 titre was $7978.57 \pm 2895.8$, it was $7094.74 \pm 2285.33$ in 160 titre, $7465.38 \pm 2693.46$ in 320 titre group and $5864.29 \pm 2118.71$ in 640 titre group. The mean difference of total count 883.83 in 160 titre group was statistically not significant ( $p$ value $=0.286$ ), 513.19 in 320 titre group was statistically not significant ( $\mathrm{p}$ value $=0.577$ ) and in 640 titre group 2114.29 was statically not significant. ( $\mathrm{P}$ - value0.067) The mean platelet in the 80 titre was $52333.98 \pm 47613.68$, it was $60631.71 \pm 35052.44$ in 160 titre, $58153.85 \pm 18365.94$ in 320 titre group and $21285.71 \pm 10209.71$ in 640 titre group.

The mean difference of platelet 8297.74 in 160 titre group was statistically not significant ( $\mathrm{p}$ value 0.468 ), 5819.87 in 320 titre group was statistically not significant (p value $=0.648)$ and in 640 titre group 31048.26 was statistically not significant. (P-value $=0.052$ ) Chang K. et. al., in a study on 81 cases have shown only $10(12.3 \%)$ had leukocytosis (leukocyte count $\geq 12.0 \times 10^{9}$ cells/L) and 8 $(13.6 \%)$ had leukopenia $\left(\leq 4.0 \times 10^{9}\right.$ cells/L). Nearly $75 \%$ of the 81 cases had normal leukocyte counts at initial presentation. Thrombocytopenia, (platelet count $<100 \times 10^{9}$ cells/L), was present in $30(37.0 \%)$ cases. In addition, prolongation of activated partial thromboplastin time (36 of $53,67.9 \%$ ) was noted more commonly than prolongation of prothrombin time (16 of $51,31.4 \%) .{ }^{[9]}$

Among people with icterus, $10(33.33 \%)$ people had 160 Overall Weil-Felix titre. The number of people with 320 and 640 Overall Weil Felix titre was 13 (43.33\%) and 7 (23.33\%) in people with icterus. Among people without icterus higher proportion of people had 80 and 160 titre. None of them had 320 and 640 titre. The mean total bilirubin in the 80 titre was $1.54 \pm 0.51$, it was $2 \pm 1.11$ in 160 titre, $4.41 \pm 1.42$ in 320 titre group and $6.63 \pm 0.76$ in 640 titre group. The mean difference of total bilirubin 0.46 in 160 titre group was statistically not significant ( $p$ value0.146), 2.87 in 320 titre group was statistically significant (p value $<0.001)$ and in 640 titre group 5.09 was statically significant. (P- Value <0.001). In one study, of the 49 cases with available serum levels of total bilirubin, hyperbilirubinemia was found in $17(34.7 \%)$ cases and $10(20.4 \%)$ cases had total bilirubin levels $\geq 34.2$ $\mu \mathrm{mol} / \mathrm{L} .{ }^{\left[{ }^{[9]}\right.}$ The mean AST in the 80 titre was $140.43 \pm 79.92$, it was $285.89 \pm 184.95$ in 160 titre, $364.92 \pm 89.69$ in 320 titre group and $579.29 \pm 106.26$ in 640 titre group. The mean difference of AST 145.47 in 160 titre group was statistically significant ( $\mathrm{p}$ value $<0.001$ ), 224.50 in 320 titre group was statistically significant ( $\mathrm{p}$ value $<0.001$ ) and in 640 titre group 438.86 was statistically significant. (P- Value <0.001) The mean ALT in the 80 titre was $154.52 \pm 112.16$, it was 295.11 \pm 200.03 in 160 titre, $375.23 \pm 113.79$ in 320 titre group and $484.14 \pm 67.93$ in 640 titre group.

The mean difference of ALT 140.58 in 160 titre group was statistically significant ( $\mathrm{p}$ value 0.003 ), 220.71 in 320 titre group was statistically significant ( $\mathrm{p}$ value $<0.001$ ) and in 640 titre group 329.62 was statically significant. (P- Value $<0.001)$ The mean ALP in the 80 titre was $149.76 \pm 64.42$, it was $209.74 \pm 85.09$ in 160 titre, $254.54 \pm 67.09$ in 320 titre group and $356.43 \pm 94.55$ in 640 titre group. The mean difference of ALP 59.97 in 160 titre group was statistically significant ( $\mathrm{p}$ value 0.015 ), 104.78 in 320 titre group was statistically significant ( $\mathrm{p}$ value $<0.001$ ) and in 640 titre group 206.67 was statically significant. (P- Value <0.001) In a study by Chang K. et. al., $19(25.7 \%)$ had normal serum levels of AST or ALT $(\leq 50 \mathrm{U} / \mathrm{L})$ whereas serum ALT levels were five times greater than normal levels in $9(12.2 \%)$ of 74 cases. Of 51 cases, $36(70.6 \%)$ had elevated serum levels of alkaline phosphatase (> $126 \mathrm{U} / \mathrm{L})$ and $35(87.5 \%)$ of 40 cases had elevated levels of lactate dehydrogenase (> $250 \mathrm{U} / \mathrm{L}) .{ }^{[9]}$ The mean urea in the 80 titre was $40.86 \pm 7.92$, it was 46.53 \pm 14.59 in 160 titre, $60.85 \pm 15.77$ in 320 titre group and $72.29 \pm 14.67$ in 640 titre group. The mean difference of urea 5.67 in 160 titre group was statistically not significant (p value 0.172 ), 19.99 in 320 titre group was statistically significant ( $\mathrm{p}$ value $<0.001$ ) and in 640titre group 31.43 was statically significant. (P- Value <0.001) The mean serum sodium in the 80 titre was $129.76 \pm 7.49$, it was $119.74 \pm$ 10.28 in 160 titre, $107.54 \pm 7.45$ in320 titre group and 100.29 \pm 7.7 in 640 titre group. The mean difference of serum sodium 10.03 in 160 titre group was statistically significant ( $\mathrm{p}$ value $<0.001$ ), 22.22 in 320 titre group was statistically significant ( $\mathrm{p}$ value $<0.001$ ) and in 640 titre group 29.48 was statically significant. (P-Value $<0.001)$.

The mean serum creatinine in the 80 titre was $1.32 \pm 0.38$, it was $1.67 \pm 0.69$ in 160 titre, $2.43 \pm 0.64$ in 320 titre group and $3.33 \pm 0.87$ in 640 titre group. The mean difference of serum creatinine 0.35 in 160 titre group was statistically not significant ( $p$ value0.077), 1.11 in 320 titre group was statistically significant ( $\mathrm{p}$ value $<0.001$ ) and in 640 titre group 2.01 was statically significant. (P- Value<0.001) Chang K. et. al., have found $6.3 \%$ of cases with acute renal failure with peak levels of serum creatinine reaching $998.9 \mu \mathrm{mol} / \mathrm{L}$ who also had lengthier stay during hospitalization. ${ }^{[9,10]}$

\section{Conclusion}

The mean heamoglobin values were statistically significantly lower in people with higher weilfelixtitre. All the liver function parameters and renal function parameters were 
significantly higher in people with weilfelixtitre of 320 and 640 , when compared to people with 80 weilfelixtitre ( $p$ value $<0.05)$.

\section{References}

1. Botelho-Nevers E, Socolovschi C, Raoult D, Parola P. Treatment of Rickettsia spp. infections: a review. Expert Rev Anti Infect Ther. 2012;10(12):1425-37.

2. Khan SA, Bora T, Chattopadhyay S, Jiang J, Richards AL, Dutta P. Seroepidemiology of rickettsial infections in Northeast India. Trans $R$ Soc Trop Med Hyg. 2016;110(8):487-94.

3. Tilak R, Kunwar R, Tyagi PK, Khera A, Joshi RK, Wankhade UB. Zoonotic surveillance for rickettsiae in rodents and mapping of vectors of rickettsial diseases in India: A multi-centric study. Indian J Public Health. 2017;61(3):174-81.

4. Blanton LS. Rickettsial infections in the tropics and in the traveler. CurrOpin Infect Dis. 2013;26(5):435-40.
5. Sagin DD, Ismail G, Nasian LM, Jok JJ, Pang EK. Rickettsial infection in five remote Orang Ulu villages in upper Rejang River, Sarawak, Malaysia. Southeast Asian J Trop Med Public Health. 2000;31(4):7335.

6. Mittal V, Gupta N, Bhattacharya D, Kumar K, Ichhpujani RL, Singh S, et al. Serological evidence of rickettsial infections in Delhi. Indian J Med Res. 2012;135(4):538-41.

7. Rahi M, Gupte MD, Bhargava A, Varghese GM, Arora R. DHR-ICMR Guidelines for diagnosis \& management of Rickettsial diseases in India. Indian J Med Res. 2015;141(4):417-22.

8. Ahmad S, Srivastava S, Verma SK, Puri P, Shirazi N. Scrub typhus in Uttarakhand, India: a common rickettsial disease in an uncommon geographical region. Trop Doct. 2010;40(3):188-90

9. Chang K, Chen YH, Lee NY, Lee HC, Lin CY, Tsai JJ, et al. Murine typhus in southern Taiwan during 1992-2009. Am J Trop Med Hyg. 2012;87(1):141-7.

10. Mathai E, Rolain JM, Verghese GM, Abraham OC, Mathai D, Mathai $\mathrm{M}$, et al. Outbreak of scrub typhus in southern India during the cooler months. Ann N Y Acad Sci. 2003;990:359-64.

Copyright: () the author(s), 2019. It is an open-access article distributed under the terms of the Creative Commons Attribution License (CC BY 4.0), which permits authors to retain ownership of the copyright for their content, and allow anyone to download, reuse, reprint, modify, distribute and/or copy the content as long as the original authors and source are cited.

How to cite this article: Naik KK, Shivaprasad. A Study on Biochemical Parametrs in Patients with Rickettsial Infection. Acad. J Med. 2019;2(2):46-50.

DOI: dx.doi.org/10.21276/ajm.2019.2.2.13

Source of Support: Nil, Conflict of Interest: None declared. 